\title{
Impact of Digitalization on Construction of Competency Models of Managerial Personnel in Sector of Industry
}

\author{
Ksenofontova Kh.Z.* \\ K.G. Razumovsky Moscow State University of \\ Technologies and Management (the First Cossack \\ University) \\ Moscow, Russia \\ e-mail xenophontova@mail.ru
}

\author{
Emtseva O.V. \\ K.G. Razumovsky Moscow State University of \\ Technologies and Management (the First Cossack \\ University) \\ e-mail o.emtseva@mgutm.ru
}

\author{
Khayrova Kh.Z. \\ Penza State University \\ Penza, Russia \\ e-mail: b.halida.tat@yandex.ru
}

\begin{abstract}
The ongoing globalization processes have an impact on changes in socio-economic aspects and the company's management system. Integration processes, innovative development of companies present new requirements for the knowledge and skills of managerial personnel. Industrial companies need defined competency models of managerial personnel at different levels of management. The purpose of the work is to substantiate the impact of digitalization on the construction of competency models of managerial personnel in a sector of industry. The main tasks are the following: to analyze scientific research and developments in the field of formation of competency models, to identify shortcomings in the process of developing models of professional competencies of managers in the context of the digitalization of the economy, taking into account the industry specialization of the company, the scope of business, the status and role of a person in the organization, to specify the requirements of global and national labor markets for the competencies of managers in the new industrial revolution.
\end{abstract}

Keywords - competency model of managerial personnel, digitalization, industry

\section{INTRODUCTION}

The digitization processes of national economies are closely linked to the new industrial revolution, which fundamentally changes production models, value systems and patterns of human behavior.

The basis of the industrial revolution and digital transformation is formed by advanced industrial technologies: the Industrial Internet of Things (IIoT), additive technologies, big data, robotics, the digital twin technology, blockchain etc., as well as new materials (composites, metal powders, polymers, metal alloys).

The current technological leaders in various branches of the world economy are the USA, Germany, Japan, Singapore and China. Many breakthrough technologies are also being tested in Russia, but their implementation is still sporadic. One of the factors hindering their more dynamic use is the lack of competencies in the field of digitalization of the economy among managers and specialists of many industrial companies. In this regard, the topical problem is the formation of new models of competencies of managerial personnel at all levels of management.

\section{METHODS AND MATERIALS}

Based on the analysis of the changes taking place in the external and internal environment caused by the new technological revolution and the transition to a digital economy, the need for deep transformations in the management systems and personnel policies of industrial companies is substantiated using the dialectical and systemic approaches. They must be adapted to modern conditions of competition in the global and national marketplace, meet the new requirements of the labor market, the needs of business, government and public institutions. The solution to these problems will be primarily associated with a shift in worldview and the acquisition of new competencies by managerial personnel [2]. This, in turn, will require the development of basic and professional models of managers' competencies for different levels of management and the corresponding professional standards.

\section{RESULTS}

A revolution occurs during the development of mankind when new technologies and methods cause changes in economic systems and social structures. The first was the agricultural revolution, which was built on the integration of the power of animals and people in order to ensure production. Industrial revolutions ensued the agricultural one. We highlighted the main ideas and elements based on the generalization of theory and practice that dominated the ideas 
about the development of industrial revolutions, the application of scientific approaches, the formation of the competencies of managerial personnel and the development of business models at different stages of evolution.

TABLE I. THE EVOLUTION OF THE DEVELOPMENT OF BUSINESS MODELS OF THE COMPANY IN THE FRAMEWORK OF INDUSTRIAL REVOLUTIONS

\begin{tabular}{|c|c|c|c|c|c|}
\hline $\begin{array}{c}\text { The name of the } \\
\text { revolution }\end{array}$ & Period & Scientific approach & $\begin{array}{l}\text { The essence of the } \\
\text { revolution }\end{array}$ & $\begin{array}{c}\text { Competencies of managerial } \\
\text { personnel }\end{array}$ & Business model \\
\hline $\begin{array}{l}\text { 1st Industrial Revolution } \\
\text { The Great Industrial } \\
\text { Revolution } \\
\text { A. Toynbee, J. Blanqui }\end{array}$ & $1780-1840$ & $\begin{array}{l}\text { The origin of "scientific } \\
\text { management" } \\
\text { Labor rationalization } \\
\text { methods }\end{array}$ & $\begin{array}{l}\text { the transition from } \\
\text { handicrafts to manufacturing } \\
\text { Production based on the } \\
\text { mechanization and use of } \\
\text { energy and steam }\end{array}$ & $\begin{array}{l}\text { Initiative } \\
\text { Prudence } \\
\text { Enterprise }\end{array}$ & $\begin{array}{l}\text { Innovation- } \\
\text { Entrepreneurship }\end{array}$ \\
\hline $\begin{array}{l}\text { 2nd Industrial Revolution } \\
\text { "Technological } \\
\text { revolution" } \\
\text { (D. Landes) }\end{array}$ & $\begin{array}{l}\text { The second half of } \\
\text { the XIXth century } \\
\text { the beginning of the } \\
\text { XXth century }\end{array}$ & $\begin{array}{l}\text { Scientific management } \\
\text { Integrated approach }\end{array}$ & $\begin{array}{l}\text { Organization of assembly- } \\
\text { line production using } \\
\text { electricity and chemicals }\end{array}$ & $\begin{array}{l}\text { Knowledge of technologies, } \\
\text { skills of standardization and } \\
\text { optimization of operations }\end{array}$ & $\begin{array}{l}\text { Mass production } \\
\mathrm{B} 2 \mathrm{C} \text { orientation }\end{array}$ \\
\hline $\begin{array}{l}\text { 3rd Industrial Revolution } \\
\text { Industria-3.0 }\end{array}$ & $\begin{array}{l}\text { The beginning of the } \\
\text { XXIst century }\end{array}$ & Resource-based view & $\begin{array}{l}\text { The introduction of digital } \\
\text { technology } \\
\text { IT-technologies and } \\
\text { automation } \\
\text { Creative Management } \\
\text { Development }\end{array}$ & $\begin{array}{l}\text { Unique knowledge and skills } \\
\text { of managerial personnel as a } \\
\text { source of competitive } \\
\text { advantages of the company }\end{array}$ & $\begin{array}{l}\text { Development of new } \\
\text { methods for creating } \\
\text { and providing value to } \\
\text { the consumer and } \\
\text { other participants in } \\
\text { market interaction }\end{array}$ \\
\hline $\begin{array}{l}\text { 4th Industrial Revolution } \\
\text { Industria-4.0 }\end{array}$ & XXIst century & Competency-based approach & $\begin{array}{l}\text { Transition to the sixth } \\
\text { technological mode } \\
\text { Service sector development } \\
\text { Concurrent } \\
\text { reindustrialization } \\
\text { Artificial intelligence }\end{array}$ & $\begin{array}{l}\text { The collaboration of } \\
\text { professional competencies of } \\
\text { managerial personnel and } \\
\text { digital technologies }\end{array}$ & $\begin{array}{l}\text { Technology platform } \\
\text { (digital platforms, } \\
\text { digital ecosystems, } \\
\text { Internet of Things) }\end{array}$ \\
\hline
\end{tabular}

In the process of evolutionary development (industrial revolution), there was a shift in the business models of industrial companies influenced by the development of the market, scientific approaches, changes of resources, development of competencies, namely: interaction with market participants; creating value for the company; creating value for the client (a set of unique resources that differ from the resources of competing companies, i.e. skills, processes, capabilities); value proposition (created taking into account the integration of the company's capabilities and consumer interests) [5].

A. Toynbee was the first to do research on the concept of "industrial revolution" in his works "Industrial Revolution of the Eighteenth Century in England." He considered the concept as a new scheme of economic, commercial and social relations [6].

In the framework of the 1st Industrial Revolution, there was a transition from the handicraft to the manufacture, which brought about the change in the social, economic, political and cultural spheres. Needs for new sales markets, sources of raw materials, areas of capital application began to develop, and the process of urbanization was stimulated. The main feature of this revolution was the industrialization, namely, there was an increase in productive forces and the establishment of capitalism as the dominant world economic system. The main competencies of this period: initiative, prudence, enterprise.

Industrial companies built business models on innovations, application of new materials and technologies. The main target of the manufacturer at the end of the XIX century was to gain confidence in the customer by lowering the barriers to obtaining a core product. Orientation to the B2C segment [8].

The Second Industrial Revolution contributed to the globalization of the economy. During this period, the USA,
Great Britain and Germany dominated the market. These countries provided $2 / 3$ of the world industrial output. The Second Industrial Revolution is associated with the appearance of mass electrification, the emergence and development of the oil industry, the invention of the automobile, the electric telegraph and the telephone, the construction of railways. Corporate forms of capital came into being, the number of hired managers and technical specialists began to grow. Knowledge of technology, standardization and optimization skills started to increase.

The business model was built on the integration of business processes, namely, on the idea that the structure determines the result.

In the process of the 3rd Industrial Revolution, Internet technologies were introduced, integrated industry value chains were breaking up, separate types of businesses and enterprises were being formed. There was a rejection of the use of minerals and a transition to renewable energy in combination with the implementation of digital technology [10, 14].

Within the framework of Industria-3.0, the following occurs: the shift of the profit center from the production stages to the R\&D centers, development and design; growth of labor productivity, reduction of the employed in production; change of centralized business models to horizontal.

The 4th Industrial Revolution makes it possible to modernize production and change the company's business models. Fully automated production, interaction with the consumer occurs within the concept of "Internet of Things". Robots interact with humans. Models of professional competencies of managerial personnel are formed in accordance with new requirements and professional standards used in the labor market. Business models of industrial companies are presented in the form of technological 
platforms that are based on the system of innovations inherent in a particular ecosystem $[12,15]$.

The Fourth Industrial Revolution is not just about smart and interconnected machines and systems. Its spectrum of action is much broader. Breakthroughs take place in a wide range of fields: from decoding information encoded in human genes to nanotechnology, from renewable energy to quantum computing. It is the synthesis of these technologies and their interaction in the physical, digital and biological domains that constitute the fundamental difference between the Fourth Industrial Revolution and all the previous ones (Schwab).

During the course of this revolution, the latest technologies and universal innovations spread faster and wider. The population of $17 \%$ of the world's territory is in contemplation of a Second Industrial Revolution since about 1.3 billion people still do not have access to electricity. Approximately half of the world's population, or 4 billion people, expects a Third Industrial Revolution since most of them live in developing countries where there is no access to the Internet.

As part of the Fourth Industrial Revolution, Industria-4.0 is being developed. This term was coined at the Hanover Fair in 2011 and was intended to refer to the process of fundamentally transforming global value chains. By spreading the technology of "smart factories", the Fourth Industrial Revolution creates a world in which virtual and physical production systems flexibly interact with each other on a global scale. This ensures complete product adaptation and the creation of new operating models. As part of Industria-4.0, the employment structure is changing, Industria-3.0 has laid off the lowest level of management, and Industria-4.0 is reducing both the middle and lower managerial levels $[3,16,20]$.

The uniqueness of the Fourth Industrial Revolution, in addition to the pace of development and wide coverage, lies in the growing harmonization and integration of a large number of different scientific disciplines and discoveries. Material innovations arising from the interdependence between different technologies, for example, the interaction of digital technologies with the biological world, material engineering, etc. There is an active development of artificial intelligence: unmanned vehicles, drones, virtual assistants, translation software. Devices become an integral part of the personal ecosystem: they listen to us, anticipate our needs, help on an as-needed basis.

The Fourth Industrial Revolution creates problems mainly in the manufacturing sector. In the majority of developed countries, as well as rapidly growing global economies such as China, there has been a percentage drop in the labor share in GDP, which is connected with the development of innovations (companies need to replace labor with capital).

Technological platforms where organizations based on digital technologies create networks connecting sellers and buyers of a wide range of products and services, thereby increasing revenues due to economies of scale.

The platform effect leads to the concentration of several powerful platforms that dominate their markets. The advantages of this are obvious, especially for consumers: higher customer value, more amenities and lower cost.
However, in this situation, certain social risks arise. To prevent the concentration of values and power in the hands of a limited number of people, it is necessary to find a way to balance the advantages and risks of digital platforms (including industrial platforms) by ensuring openness and opportunities for collective innovation.

These fundamental changes, affecting economic, social and political systems, are difficult to undo, even if you try to somehow reverse the process of globalization itself.

Initially, competency models were looked into by D.C. McClelland, who proposed a model of 21 competencies. Gaugler and Thornton formed a model of 6 competencies [4]. Russell believed that only four competencies were needed, of which the most important were interpersonal and problemsolving skills.

So, in 1998-1999, the models of leading companies were presented in the Competency and People Management journals. ABB presented a competency model of the following components: skills - teamwork, customer focus, communication skills, development of others, leadership - and personal qualities - flexibility, quality, creativity, responsibility. IBM identified the following competencies: skills - teamwork, decision making, leadership, customer understanding - and personal qualities - personal dedication, passion for work, directness. KPMG built the model of managerial competencies on 6 skills: responsibility for the client, business skills, management, social skills, thinking skills, skills of developing other people. And only the Xerox competency model in addition to the manager's skills and personal qualities, considers their abilities, such as: implementation of strategy, strategic thinking, the vision of prospects for the industry (Woodruff p. 128). Analyzing the competency models of managers of foreign companies, it should be noted that they are characterized by a generalized nature and there is no clear arrangement of the set of competencies into the corresponding level of management in the company $[1,17]$.

Special attention is presently paid to the development of models of managers' competencies by representatives of scientific schools in Great Britain, Germany, and France. Representatives of each school interpret the competency model in their own way. British scientists (J. Cheatham, J. Chivers, J. Raven) consider the manager's competency model as an interconnection of cognitive, functional, personal, ethical competencies and meta-competencies. Their competency model is based on professional standards. American scientists (Spencer L.M., Spencer S.M.) consider the manager's competency model as a set of his knowledge and skills. Representatives of the French scientific school (G. Arnaud, D. Casal, A. Dietrich) believe that the manager's competency model is an integration of three elements: knowledge, experience and behavioral characteristics. German scientists (S. Blomenk, J. Lehman), like the British, consider the managerial competency model as a set of qualification standards. In the works of the Russian scientists A.V. Ovchinnikov, O.A. Chulanova, E. I. Kudryavtseva, the manager competency model is presented in the form of the 
interrelation of managerial competencies with their value characteristics $[7,11,18]$.

The methodological paradox that arose as a result of the rapid development of the theory of competencies lies in the fact that the adequate use of the competency model in corporate practice requires a clear understanding of the reality, the object and the subject.

Corporate competency models have advantages as they correspond to the culture of the company and its needs. These competency models of managerial personnel are developed independently. An example of this model is the UCF model, which has a three-level structure, so the highest level contains 8 general competencies, the middle level comprises 20 competencies, and the lower level constitutes 112 competencies. Modern companies with a project, flat management structure form the IPMA manager's competency model, where contextual, behavioral and technical competencies are highlighted. In 2019, a survey was conducted of 40 leading Russian and Western companies to study the standard competency model of mid-level managers. The interview was attended by 141 top managers. Based on the results of the survey, the standard model of competencies for middle-level managers named "20 faces" was developed, which includes: managerial skills, decision-making skills, motivation, individual traits, interpersonal skills [19].

So the competency model of the IMC manager of the British company SHL includes 16 competencies, which are allocated in 4 blocks: managerial qualities, entrepreneurial qualities, professional qualities and personal qualities. The American company S. Whiddett \& S. Hoolyforde identifies the following competencies in the model: business development, the achievement of results, analysis, work with information, personnel. A Japanese company bases its competency model on the multi-professional manager. Dutch industrial companies form models of managerial competencies including system management skills, decision-making skills, analysis skills of the external and internal environment, communication skills, responsiveness, business communication and personal qualities. The Russian company SIBUR has a managerial competency model that includes six components: leadership, discipline of execution, strategic vision, development of people and building effective teams, openness to change and corporate nature [21]

The leaders in the digitalization of industry are countries like the USA, Germany, Japan, Singapore, China, the Netherlands, Great Britain, South Korea and Sweden [16]. At the same time, the level of industrial digitalization in all countries of the world has been increasing in recent years. So, in Germany, it is $33 \%$, and by 2021 it is planned to increase its share to $82 \%$. The share of digital technologies in production processes in Germany, according to predictive estimates, may grow by an average of 3.8 times by 2022, incl. in mechanical engineering - by 4.5 times, automotive -4.4 , electronics / electrical engineering - 3.4, IT-technology - 3 [20].

German enterprises operating since 2011 as part of the Industria-4.0 concept have increased labor productivity by 18 $\%$. In the USA, within the framework of the Advanced
Manufacturing Partnership program, a consortium of Industrial Internet was formed; in China, the concept of "Made in China 2025" was approved and is in force; in Japan, the concept of "Connected Factories" is discussed (it involves the use of "smart" enterprises of Internet networks); in Russia, the technological track "Technet" [20] is being formed. Russian enterprises such as PAO "Rostekhnologii", the Rosatom Concern, PAO "Gazprom", PAO "Sibur", PAO "Rosneft", PAO "Sberbank" are also introducing the Industria-4.0 concept in their activities using the following components: product engineering (3D modeling, "digital twins"), method of product production (digital footprint, MES, ERP data), ecosystem formation and environmental friendliness [13, 19].

However, in Russia, there are significant barriers to the introduction of digital technologies by industrial companies [21]. There are no common interfaces, high-tech equipment, network technologies are not well developed, modern communications between production lines and managerial staff are poorly developed, document management is not fully automated, etc.

An important condition for the successful functioning of digital production is the presence of highly qualified managers and specialists with relevant professional knowledge and skills. According to a survey by The Boston Consulting Group, in order to implement the "digital revolution" until 2025, Russia will need up to 9 million highly qualified personnel. Currently, only $17 \%$ of top managers in Russia have professional knowledge of changing the business model and business processes using IT systems and modern technologies [9, 20].

Most managers also do not have the skills to work in a new industrial revolution, develop and make managerial decisions that are adequate to the requirements of the digital economy [15].

To change the current situation requires the development of new competency models for all categories of managers of industrial companies. The professional models of managers should be adapted from the base competency model (BCM).

The developers of the BCM have not clearly defined the methodology for its construction; as a result, this model has neither been developed nor presented. In our opinion, the BCM may include the following components.

From our point of view, the BCM should include a core containing digital competencies that are interconnected with basic knowledge, value system, communication skills, personal qualities and manager's self-development skills.

Based on the BCM, models of professional competencies of managers will be formed taking into account its industry affiliation, legal form, size of the company, its capital structure, as well as the position and status of managers.

The professional competency model of a top manager, built on the basis of the BCM, should include a combination of knowledge and skills that allow us to formulate a long-term vision, develop a strategy and business model for the development of the company, provide inspiring leadership, team building, motivation for employees, and take reasonable 
management decisions. In the context of the digitalization of the economy, managers of the highest level should pay special attention to the formation of internal mechanisms of motivation and self-organization, control and selfdevelopment. Any managerial influence of senior management should be skillfully included in the processes of selforganization through the formation of mechanisms of selfmanaged development, when management, based on inspiring leadership, carries out initiating excitement of personnel, creates motivational attitudes to self-management. The solution to these problems will be greatly facilitated by modern information and communication technologies and a high level of automation of production and service processes.

Depending on the degree of the manager's command of the competencies necessary for his professional activity, as well as changes occurring in the external and internal environment, adjustments to the competency model should be made in a timely manner.

The effectiveness of decisions made at the top management level of a company largely depends on their implementation at the tactical and operational levels of management.

Mid-level managers are the link between the upper and lower levels of management. The competencies of middle managers should ensure the establishment and implementation of the tactical goals and objectives of an industrial enterprise. The managers of this level of management are responsible for the implementation of decisions made at the highest level of management. They are designed to organize the activities of functional units, to build and control business processes, working closely with the leaders of the lower level of management.

In the context of the growing scale of production automation, and in the long run the wider use of artificial intelligence, the functions and roles of managers and methods of making managerial decisions at the middle and lower levels of management will significantly change.

In the competency models of mid-level managers, the share of knowledge and skills in the field of information and new industrial technologies, team and design working methods will increase in order to accelerate operating cycles, reduce costs and increase labor productivity, as well as their interest and ability to adapt to constant changes. All this will require a higher level of self-organization and self-development for effective interaction with both top managers and bottom-level managers (foremen).

In our opinion, the functions of lower-level managers will undergo the greatest transformation, as they can be taken over by the most skilled workers, whose role in the conditions of a high level of production automation will be reduced to monitoring and controlling the course of production processes. "Smart" machines themselves will be responsible for organizing business processes in accordance with the software settings specified to them. The hours and schedules will also change. The formation of digital platforms, the organization of distributed production and business ecosystems will lead, on the one hand, to the desire for remote forms of work with a flexible schedule, on the other hand, industrial companies will have the opportunity to attract other organizations in the form of outstaffing or freelancers (independent specialists who participate in the project before it is carried out), for example, portfolio managers with unique knowledge and skills in the field of planning and running projects.

Successful adaptation to new operating conditions will undoubtedly require managers of industrial companies to make certain changes to the values, norms and behaviors of both themselves and employees. This is one of the most difficult tasks since it is related to the mentality and people's awareness of the changes that are taking place.

\section{CONCLUSION}

In the context of the new industrial revolution and the digitalization of the economy, profound changes are taking place in all spheres of human life. New technologies and emerging cyber-physical systems require significant changes in production processes, ways of using the material, financial, information and human resources in order to ensure the competitiveness of companies in the global and national markets for goods and services, labor and capital. In this regard, industrial companies should determine their organizational identity, form a long-term vision, develop strategies and business management models that are adequate to these requirements. The managerial body is called upon to solve these problems by acquiring the appropriate knowledge and skills and being able to employ them in new realities.

\section{References}

[1] O. Gassman, K. Frankenberger, M. Schick, Business models: 55 bes templates, Alpina Publ., 2016, 432 p.

[2] R. Daft, Management, 8rd ed., Trans. from English Ed. S.K. Mordovina Peter, 2009, 800 p.

[3] Kh.Z. Ksenofontova, "Competence models of various categories of management personnel”, Personnel Management, vol. 17, pp. 83-87, 2009

[4] Kh.Z. Ksenofontova, "Business model and strategy of industrial company management", The Europ. Proc. of Soc. \& Behavioural Sci. (EpSBS), pp. 600-606, 2018, Retrieved from: https://doi.org/10.15405/epsbs/2018.12.78

[5] L. V. Labunsky, "Development of competencies of the personnel of the mining enterprise", Uro RAS, 232 p., 2003

[6] E.A. Neretina, "System dynamics and multyframing thinking leader and managers of the organization”, Russ. J. of manag., no. 1, pp. 54-60, 2015.

[7] S.N. Parkinson's, M.K. Rustomji, Art of management. Lenizdat, 1992 $143 \mathrm{p}$.

[8] A.I. Prigozhin, Goals and values. New methods of working with the future. Publ. house "Delo", the Acad. of national econ., 2010, 432 p.

[9] Ph. Selznick, Leadership in Administration. New York: 1957, 197 p.

[10] Business Management, Trans. from English, 3rd ed., Alpina Publ., 2018, 290 p.

[11] M. Homich, Y. Mitin, Millions on butterflies, or the History of the most interesting business models. Publ. house "E", 2016, 224 p.

[12] V.N. Bobkov, Y.G. Odegov, V.V. Pavlova, "Precarious employment in present-day Russia: Relevant worker profiles, Int. J. of Engineer. and Technol. (UAE), vol. 7, no. 4, pp. 72-77, 2018

[13] I.V. Tarasov, N.A. Popov, "Industria-4.0: transformation of manufactures", Strategic Decisions and Risk Management, no. 1, pp. 38-53, 2018. 
[14] O.L. Chulanova, G.H. Kucherenko, D.V. Chulanov, A.V. Kirillov, A.V. Melnichuk, "Crowd-technology in the selection of personnel", Europ. Res. Studies J., vol. 20, no. 4, pp. 380-397, 2017.

[15] Y.A. Salikov, I.V. Logunova, I.V. Kablashova, "Trends in human resource management in the digital economy", Proc. of Voronezh State Univers. of Engineer. Technol., vol. 81, no. 2, pp. 393-399, 2019, Retrieved from: https://doi.org/10.20914/2310-1202-2019-2-393-399

[16] N.N. Kudryavtseva, Y.V. Pakhomova, Y.N. Duvanova, "The concept of management development management enterprise", Proc. of Voronezh State Univer. of Engineer. Technol., vol. 81, no. 1, pp. 429-433, 2019, Retrieved from: https://doi.org/10.20914/2310-1202-2019-1-429-433

[17] .S. Serebryakova N, A.V. Petrikov, "The principles of design and the organization of functioning of innovative infrastructures in the conditions of the Industry 4.0", Proc. of Voronezh State Univer. of
Engineer. Technol., vol. 80, no. 4, pp. 384-387, 2018, Retrieved from: https://doi.org/10.20914/2310-1202-2018-4-384-387

[18] O.O. Lukina, V.V. Dudchak, "Generalized indicator and classification structures of the capital of the industrial enterprises", Proc. of Voronezh State Univer. of Engineer. Technol., vol. 80, no. 3, pp. 423-428, 2018, Retrieved from: https://doi.org/10.20914/2310-1202-2018-3-423-428

[19] N.A. Azarova, A.Y. Nebesnaya, A.S. Sviridov, L.E. Glagoleva, "Analysis of human capital in the region as a source of import substitution", Proc. of Voronezh State Univer. of Engineer. Technol., vol. 80, no. 3, pp. 451-457, 2018, Retrieved from: https://doi.org/10.20914/2310-1202-2018-3-451-457

[20] Business and Information Technology. Retrieved from: http://bit.samag.ru

[21] HighAdvance Consulting Group. Retrieved from: http://highadvance.org 